\title{
Rustia kosnipatana (Rubiaceae, Cinchonoideae), a New Species from the Kosñipata Region in Southern Peru
}

\author{
Sabine Will \\ University of Vienna, Department of Biogeography, Rennweg 14, 1030 Vienna, Austria. \\ sabinewill@gmx.at \\ Charlotte M. Taylor \\ Missouri Botanical Garden, P.O. Box 299, St. Louis, Missouri 63166-0299, U.S.A. \\ charlotte.taylor@mobot.org
}

Abstract. Three species of Rustia Klotzsch (Rubiaceae, Cinchonoideae) were previously known from Peru, R. rubra Standl. ex D. R. Simpson, $R$. schunkeana Delprete, and R. viridiflora Delprete. A fourth species from the Kosñipata Valley (Cuzco Department), R. kosnipatana S. Will \& C. M. Taylor, is newly described and illustrated here. This tree species differs in its inflorescences with erect pink flowers, fusiform flower buds, and corollas with dense pubescence in the throat and the lobes longer than the tubes. This is the first record of Rustia in the southern zone of Peru.

Resumen. Tres especies de Rustia Klotzsch (Rubiaceae, Cinchonoideae) se conocen de Perú: R. rubra Standl. ex D. R. Simpson, R. schunkeana Delprete y $R$. viridiflora Delprete. Una cuarta del valle de Kosñipata (Departamento de Cuzco), R. kosnipatana S. Will \& C. M. Taylor, se describe e ilustra aquí. La especie se distingue por su hábito arbóreo, las inflorescencias con flores erectas y rosadas, las yemas florales fusiformes y las corollas con densa pubescencia en la garganta y los lóbulos más largos que el tubo. Este es el primer registro de Rustia en la zona sur de Perú.

Key words: IUCN Red List, Neotropics, Peru, Rondeletieae, Rubiaceae, Rustia.

Rustia Klotzsch (Rubiaceae, Cinchonoideae) is a Neotropical genus of about 15 species, found from Guatemala to Peru and southeastern Brazil (Delprete, 1999). The genus includes understory shrubs to midcanopy trees of primary and secondary evergreen forests, from sea level up to $2000 \mathrm{~m}$. Rustia is distinguished by its combination of caducous, triangular, interpetiolar stipules; leaves often with pellucid glands; terminal, multiflowered, paniculate or thyrsiform inflorescences; corollas with well-developed tubes and the lobes valvate in bud; poricidal anthers; and loculidal, woody to papery, generally ellipsoid to obovoid capsules with numerous small, angled to flattened seeds. The calyx limbs are persistent on the fruits but in general reduced to a dentate or sinuate margin. A few other Rubiaceae also have leaves with pellucid-punctate leaves, e.g., Heterophyllaea Hook. $\mathrm{f}$., but this character is unusual in Rubiaceae. Rustia belongs to a group of genera whose relationships within the Rubiaceae are not yet clear. It was included in the Rondeletieae by Delprete (1999), but subsequent study (Rova et al., 2002) found it related to several Neotropical genera that had previously been placed in several other tribes, and Robbrecht and Manen (2006) found these genera mostly unrelated and did not classify Rustia, but placed its apparent sister genus Molopanthera Turcz. in Henriquezieae.

The species of Rustia treated by Delprete (1999) were distinguished by morphological characters, and in general also show notable biogeographic separation with the species having relatively similar corollas all occupying distinct ecological and geographic ranges. Delprete considered the shape of the flower bud, fusiform versus clavate, to be a species-level character. Anthers in Rustia open by pores near the apex instead of linear slits; this is uncommon in the Rubiaceae. Puff et al. (1995) noted that although the stamens of Rustia do not form an anther cone and therefore do not fall into the "Solanum-type" of pollen flowers category, the presence of buzz-pollination within this genus cannot be excluded, and Delprete (1999: 30) reported this pollination mechanism in $R$. occidentalis (Benth.) Hemsl. Delprete also detailed variation in the shapes of the anthers of different species, in particular these sometimes have caudate bases, various ornamentations or prolongations of the connective pubescence arranged in distinctive patterns, or an unusual spheroidal projection at the base of each theca (Delprete, 1999: 79, fig. 33, $R$. schunkeana, though not mentioned in textual description). At present, no particular functions or correla- 
tions with pollination mode have been proposed for any of these structures.

Rustia was not reported from Peru (Standley, 1936) until Simpson (1976) documented two species of this genus from here: R. rubra Standl. ex D. R. Simpson and $R$. secundiflora K. Schum. Rustia was monographed by Delprete (1999), who also reported two species from Peru: $R$. rubra and $R$. schunkeana Delprete; he treated the name $R$. secundiflora as a synonym of $R$. thibaudioides (H. Karst.) Delprete, found in Colombia, Venezuela, and adjacent Brazil, and included the Peruvian plants treated under that name by Simpson in the newly described species $R$. schunkeana. Subsequently, a third species, $R$. viridiflora Delprete, was provisionally reported from Peru based on a fruiting specimen (Ulloa Ulloa et al., 2004). Another Rustia species described from Peru, $R$. isernii Standl., is now treated as Agouticarpa isernii (Standl.) C. Persson (Persson, 2003).

We here describe a fourth species of Rustia from Peru, R. kosnipatana S. Will \& C. M. Taylor, based on specimens collected during recent exploration, and provide a key to separate these four species.

\section{Key to Peruvian Species of Rustia}

1. Shrubs $3-5 \mathrm{~m}$ tall; corolla greenish yellow ..... . . . . . . . . . . . R. schunkeana

$1^{\prime}$. Trees 10-20 m tall; corolla green, red, pink, or red with green lobes; anthers without spheroidal projections.

2. Inflorescences with pendulous flowers; corolla tubes glabrous or strigose inside, with lobes ca. 1/10 of total corolla length...... R. rubra

$2^{\prime}$. Inflorescences with erect to spreading flowers; corolla tubes glabrous to densely pubescent inside, with lobes $1 / 4-2 / 3$ of total corolla length.

3. Corolla with tube 4-6 mm long, densely pubescent in throat, with lobes ca. $2 / 3$ of total corolla length, longer than tube; southern Peru........ R. kosnipatana

3'. Corolla with tube 14-18 mm long, glabrous in throat, with lobes $1 / 4-1 / 3$ of total corolla length, shorter than tube; northern Peru.......... R. viridiflora

Rustia kosnipatana S. Will \& C. M. Taylor, sp. nov. TYPE: Peru. Cuzco: Prov. Paucartambo, Dist. Kosñipata [Qosñipata], Pillocopata, Pongo de K'conic, $12^{\circ} 54^{\prime} \mathrm{S}, 071^{\circ} 22^{\prime} \mathrm{W}, 780 \mathrm{~m}, 28$ June 2003, I. Huamantupa 3499 (holotype, CUZ; isotypes, MO 6208805, WU). Figure 1.

Haec species a congeneris lamina foliari obovata usque oblanceolata, inflorescentia paniculiformi longitudine $30 \mathrm{~cm}$ excedente flores erectos ferente, alabastro fusiformi, flore 10-16 mm longo (lobulis corollinis inclusis) atque corolla intus pubescente lobulis corollinis patentibus quam tubo ca. 2/3 longioribus distinguitur.
Trees to $13 \mathrm{~m}$ tall. Leaves with blades obovate to oblanceolate, 14-32 × 6-12 cm, cuspidate to acuminate at apex, acute at base, glabrous on both surfaces, with secondary veins 13 to 19 pairs, weakly interconnecting near margins, domatia absent, on both surfaces with costa and secondary venation prominulous and minor venation hardly visible; petioles 2$5 \mathrm{~cm}$, glabrescent, swollen at base, becoming lignified and brown when dry; stipules triangular, 1.5-3 cm, early deciduous, in bud strongly twisted at apex and possibly resinous. Inflorescences paniculiform, pyramidal, 30-55 × 30-50 cm, secondary axes opposite; peduncle 6-9 cm; basalmost secondary axes 15$25 \mathrm{~cm}$, glabrous; bracts subtending secondary and tertiary axes $2-4 \mathrm{~mm}$; bracteoles $1-1.5 \mathrm{~mm}$, obtuse to rounded, ciliolate; pedicels $2-12 \mathrm{~mm}$. Flowers in bud fusiform; hypanthium 3-6 mm; calyx limb tubular, 2$3 \mathrm{~mm}$, dentate to sinuate, glabrous, ciliolate; corolla tubular with spreading lobes, pink, 10-16 mm, glabrous outside, tube $4-6 \mathrm{~mm}$, ca. $2 / 3$ as long as lobes, internally densely pubescent around throat with two kinds of trichomes, one in a ring inside throat of ascending trichomes that dry yellow to brown, the other in discrete groups at bases of filaments of retrorse trichomes, lobes 4 to $5,6-10 \mathrm{~mm}$, densely pubescent adaxially with short ascending trichomes that dry yellow to brown; stamens 4 or 5 , exserted, filaments 4-6 mm, inserted just below corolla throat, anthers narrowly oblong, ca. $2 \mathrm{~mm}$, papillate; style 8$10 \mathrm{~mm}$; stigmas linear, ca. $1 \mathrm{~mm}$, exserted. Fruits not seen.

Habitat, distribution, and phenology. Rustia kosnipatana is known from premontane primary forest at ca. $780 \mathrm{~m}$ in the vicinity of Manú National Park in southern Peru; it has been collected with flowers in June.

IUCN Red List category. This species is known from one collection, which was made as part of a general survey assessing only floristic presence in a very poorly known area. Because essentially nothing is known about the population size, distribution, and dynamics of this new species and thus the condition of its habitat also cannot be assessed, it is here considered to lack adequate information for an assessment of its conservation status. Thus using the IUCN (2001) categories, this species is here considered Data Deficient (DD).

Discussion. Rustia kosnipatana can be distinguished from other species of Rustia by the combination of its obovate to oblanceolate leaf blades; its relatively large, erect, paniculiform inflorescences; its fusiform flower buds; and its relatively short corollas that are densely pubescent in the throat and have 

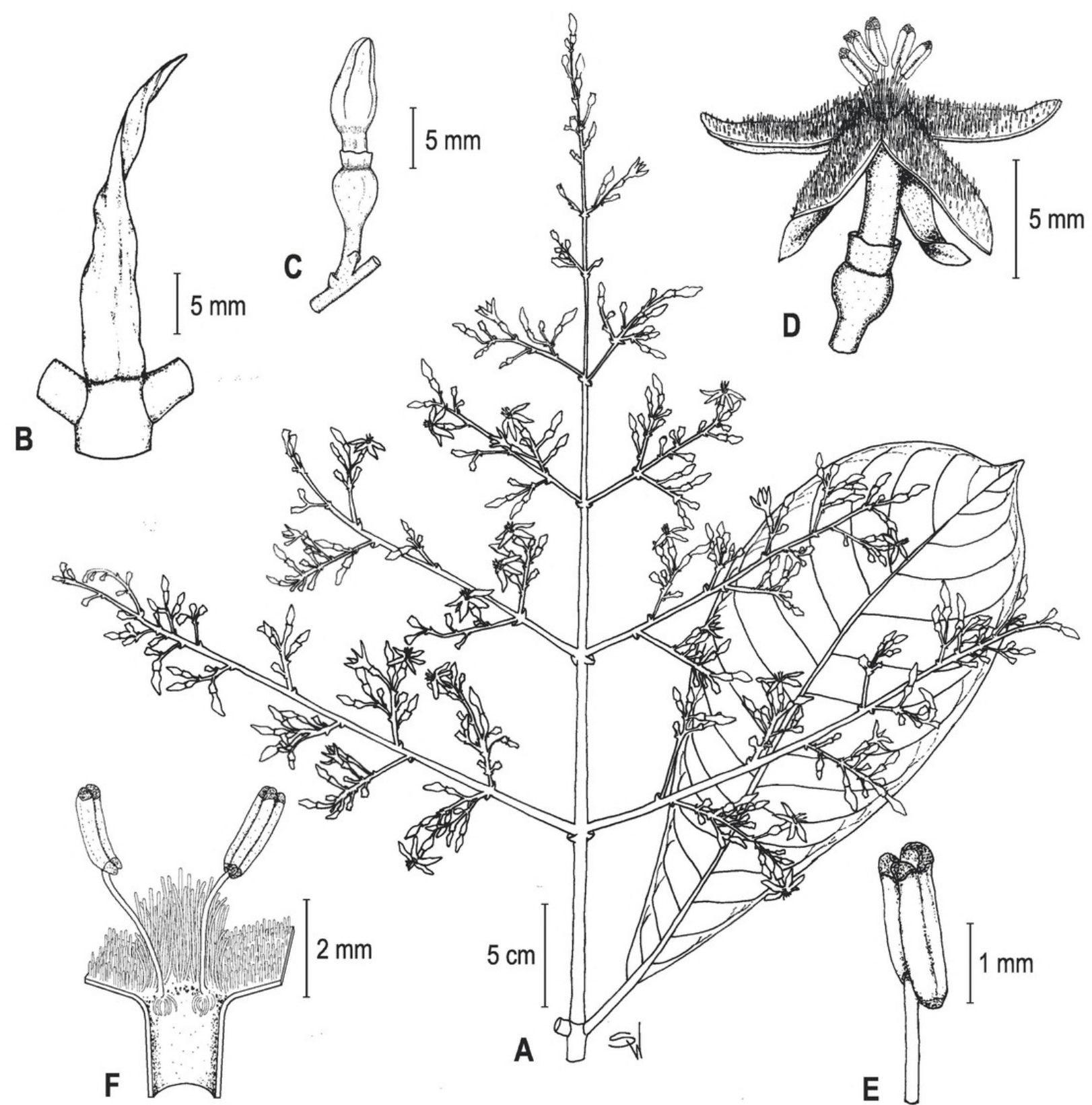

Figure 1. Rustia kosnipatana S. Will \& C. M. Taylor. - A. Flowering stem with mature leaf. -B. Terminal stipule. -C. Flower bud. - D. Flower. - E. Stamen with open anther. - F. Detail of pubescence near the corolla throat. Drawn by S. Will from the isotype Huamantupa 3499 (WU).

well-developed, spreading lobes that are longer than the tubes. Although only one specimen has been seen and the fruits are as yet unknown, the poricidal anthers, pellucid-punctate leaves, interpetiolar stipules, and paniculiform inflorescences clearly identify it as belonging to Rustia, and its corollas are unique and clearly distinguish it within this genus.

Outside of Peru, Rustia kosnipatana is similar in its corolla form and pubescence to two other species. One is R. formosa (Cham. \& Schltdl. ex DC.) Klotzsch from southeastern Brazil; however, $R$. formosa differs in its larger corollas with the tubes $9-12 \mathrm{~mm}$ long and its lobes equal to or shorter than the tubes. Rustia alba
Delprete, from premontane and montane forests at $1500-2400 \mathrm{~m}$ on the western slopes of the Andes in northwestern Ecuador, is also very similar to $R$. kosnipatana; however, $R$. alba differs in its mostly broader leaves, $13-16 \mathrm{~cm}$ wide; its white corollas that are glabrous in the throat and on the adaxial surfaces of the lobes; and its larger anthers, 6.5-7 mm long.

This new species was documented by the inventory of tree diversity in the Pongo of Qoñec or K'conic forest in the Kosñipata Valley, in the vicinity of the Manú Biosphere Reserve. Huamantupa Chuquimaco (2005) noted the difficult access and very limited botanical knowledge of this area, and commented that 
several apparently endemic species have been found here. The name of $R$. kosnipatana refers to its collection locality.

Acknowledgments. The authors thank R. Gereau for the Latin translation, R. Buchner for his help with scanning the figure, and two anonymous reviewers for helpful comments. Travel to the Missouri Botanical Garden by the first author was supported by the University of Vienna (Dean of Students and DLE Research Services) and the Siegfried Ludwig Fonds.

\section{Literature Cited}

Delprete, P. G. 1999. Rondeletiae (Rubiaceae)—Part I. Fl. Neotrop. Monogr. 77. New York Botanical Garden Press, Bronx.

Huamantupa Chuquimaco, I. 2005. Vochysia kosñipatae (Vochysiaceae), una nueva especie endémica en el Pongo de Qoñec, Valle de Kosñipata, Cusco-Perú. Arnaldoa 12(1-2): 82-85.

IUCN. 2001. IUCN Red List Categories and Criteria, Version 3.1. Prepared by the IUCN Species Survival Commission. IUCN, Gland, Switzerland, and Cambridge, United Kingdom.
Persson, C. 2003. Agouticarpa, a new neotropical genus of tribe Gardenieae (Rubiaceae). Brittonia 55(2): 176-201.

Puff, C., A. Igersheim, R. Buchner \& U. Rohrhofer. 1995. The united stamens of Rubiaceae. Morphology, anatomy; Their role in pollination ecology. Ann. Missouri Bot. Gard. 82: 357-382.

Robbrecht, E. \& J.-F. Manen. 2006. The major evolutionary lineages of the coffee family (Rubiaceae, angiosperms). Combined analysis (nDNA and cpDNA) to infer the position of Coptosapelta and Luculia, and supertree construction based on $r b c L, \operatorname{rpsl6}$, trnL-trnF and atpB$r b c L$ data. A new classification in two subfamilies, Cinchonoideae and Rubioideae. Syst. Geogr. Pl. 76: 85-146.

Rova, J. H. E., P. G. Delprete, L. Andersson \& V. A. Albert. 2002. A trnL-F cpDNA sequence study of the Condamineeae-Rondeletieae-Sipaneeae complex with implications on the phylogeny of the Rubiaceae. Amer. J. Bot. 89(1): 145-159.

Simpson, D. R. 1976. Studies in neotropical Rubiaceae. I. Rustia. Phytologia 33(1): 4-8.

Standley, P. C. 1936. Rubiaceae. Pp. 3-261 in J. F. Macbride (editor), Flora of Peru. Field Mus. Nat. Hist., Bot. Ser. 13(6). Field Museum, Chicago.

Ulloa Ulloa, C., J. L. Zarucchi \& B. León. 2004. Diez años de adiciones a la flora del Perú: 1993-2003. Arnaldoa, Ed. Esp., 1-242. 

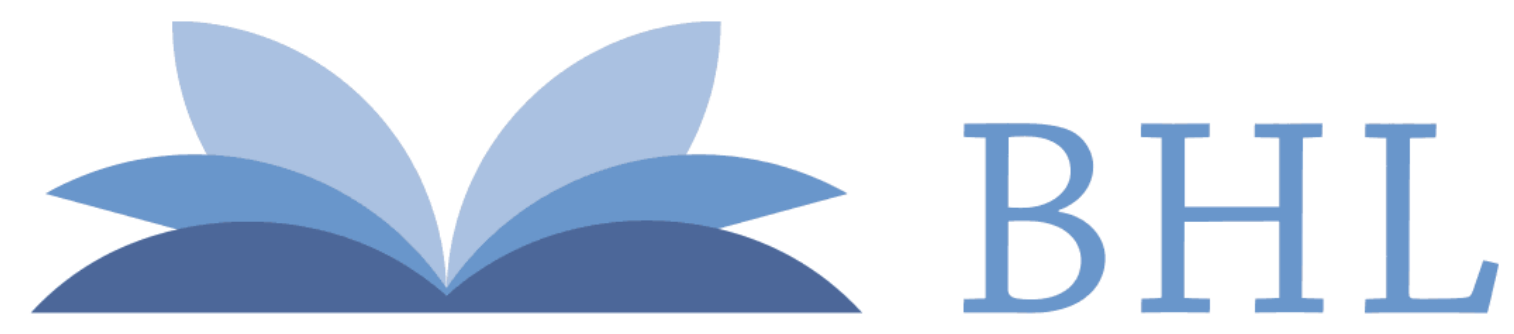

\section{Biodiversity Heritage Library}

Will, Sabine and Taylor, Charlotte M. 2010. "Rustia kosnipatana (Rubiaceae, Cinchonoideae), a New Species from the Kosñipata Region in Southern Peru." Novon a journal of botanical nomenclature from the Missouri Botanical Garden 20, 503-506.

View This Item Online: https://www.biodiversitylibrary.org/item/123332

Permalink: https://www.biodiversitylibrary.org/partpdf/122062

\section{Holding Institution}

Missouri Botanical Garden, Peter H. Raven Library

\section{Sponsored by}

Missouri Botanical Garden

\section{Copyright \& Reuse}

Copyright Status: Permission to digitize granted by rights holder Rights: https://www.biodiversitylibrary.org/permissions

This document was created from content at the Biodiversity Heritage Library, the world's largest open access digital library for biodiversity literature and archives. Visit BHL at https://www.biodiversitylibrary.org. 